\title{
"New Normal" in Learning and Teaching
}

\author{
*B K Prahani ${ }^{1}$, T-H Cheng ${ }^{2}$ \\ ${ }^{1}$ Department of Physics, Faculty of Mathematics and Natural Science, Universitas Negeri Surabaya, Surabaya 60231, \\ Indonesia \\ ${ }^{2}$ Graduate Institute of Science Education, National Dong Hwa University, Hualien 97401, Taiwan
}

\begin{tabular}{|c|c|}
\hline Article Info & ABSTRACT \\
\hline $\begin{array}{l}\text { Article history: } \\
\text { Received August, } 292020 \\
\text { Revised August, } 312020 \\
\text { Accepted August, } 312020 \\
\text { Available Online August, } 312020 \\
\end{array}$ & $\begin{array}{l}\text { Social distancing and physical distancing policies have been } \\
\text { implemented in many countries for some time in the face of a } \\
\text { COVID- } 19 \text { pandemic. The new policy that has been adopted by } \\
\text { many countries is "New Normal". New Normal is a scenario to } \\
\text { accelerate the handling of COVID-19 in health and socio-economic }\end{array}$ \\
\hline $\begin{array}{l}\text { Keywords: } \\
\text { Education } \\
\text { Learning } \\
\text { New Normal } \\
\text { Teaching }\end{array}$ & $\begin{array}{l}\text { aspects. One of them is the Government of Indonesia has } \\
\text { announced plans to implement new normal scenarios by } \\
\text { considering epidemiological studies and regional readiness. With } \\
\text { the implementation of New Normal, education will be run again } \\
\text { according to the health protocol. New Normal policies in education } \\
\text { must also be in line with instructions issued by The United Nations } \\
\text { Agency for Child Welfare (UNICEF). UNICEF has issued } \\
\text { guidelines for countries that want to reopen teaching and learning } \\
\text { activities in schools. The guide consists of three stages, namely } \\
\text { before opening, entering the opening process, and when opening } \\
\text { has been carried out. Research on the planning, preparation, } \\
\text { implementation, and evaluation of New Normal in the field of } \\
\text { learning and teaching needs the attention of all parties, including } \\
\text { academics. The results of research and publications on the impact } \\
\text { of New Normal in the field of learning and teaching are believed to } \\
\text { be beneficial in the field of education. }\end{array}$ \\
\hline
\end{tabular}

COVID-19 pandemic has caused many countries to work extra hard so that the number of cases of infection does not continue to soar and the death rate of Covid-19 patients can be suppressed. Based on Worldometers data, as of 17:00 Jakarta Time, May 27, 2020, the total positive cases of COVID-19 in the world reached 5,704,077 patients today (Worldmeters, 2020). This means that there has been an increase of almost 100 thousand new cases in the last day. Of the 5.7 million positive cases of COVID-19, 352,669 people have died since the Covid-19 pandemic began in late 2019 and continues today. Conversely, the number of Covid-19 patients in the world who have recovered has reached 2,447,424 people. Worldometers noted that there were 2,903,984 active cases or patients who still had to undergo treatment and isolation. About 2 percent or 53,104 patients are in critical condition.

Social distancing and physical distancing policies have been implemented in many countries for some time in the face of a COVID-19 pandemic. The COVID-19 pandemic is now beginning to spread to the world of education. The Ministry of Education and Culture (MOEC) is currently based on official information, ready with all scenarios, including encouraging online learning for students (Abidah et al., 2020). The new policy that has been adopted by many countries is "New Normal". New Normal is a scenario to accelerate the handling of COVID-19 in health and socio-economic aspects. One of them is the Government of Indonesia 
has announced plans to implement new normal scenarios by considering epidemiological studies and regional readiness.

With the implementation of New Normal, education will be run again according to the health protocol. New Normal policies in education must also be in line with instructions issued by UNICEF. The United Nations Children's Fund (UNICEF) has issued guidelines for countries that want to reopen teaching and learning activities in schools. The guide consists of three stages, namely before opening, entering the opening process, and when opening has been carried out.

During the pre-school opening, the following things must be prepared:

* Develop clear guidelines for indicators of school opening. Opening can be started from the area with the lowest risk. Opening can also be done in stages, starting from limiting the days of entering school or certain levels first.

* Prepare clear guidelines regarding the enforcement of social distancing in schools.

* Establish clear guidelines regarding health and hygiene protocols that must still be maintained at school.

* Revise the portion of attendance in determining the value of lessons.

* Protection of teaching staff who are at high risk due to age and health conditions, and preparing plans to replace teachers who cannot teach.

* Develop funding needs to improve the quality of school hygiene.

* Building emergency response facilities such as shelters, health units, quarantine locations, and so on.

* Provides training for teachers to support the learning process from a distance.

* Compile changes in the academic calendar that includes various scenarios in the health sector.

* Ensuring that teachers' salary payments remain intact and are able to support a decent life.

* Providing financial assistance to schools affected by the corona virus pandemic.

* Children from marginalized groups deserve priority access to education.

Meanwhile, when entering the reopening process, the guidelines emphasized by UNICEF (2020) are:

* Improve communication and coordination from the school to students, parents, and the community.

* Increasing the supply of clean water to schools, including improving the quality of sanitation.

* Providing training to teachers and school staff to uphold social distancing and clean-living practices.

* Establish procedures when students, teachers or school staff feel unwell by increasing coordination with local health authorities.

* Revising school fees.

* Completing teacher knowledge to guide students in mental health and psychosocial aspects.

* Implement large-scale learning to increase the literacy level of early childhood and children with special needs.

* Develop risk assessments for teachers with certain conditions (elderly or have medical conditions). 
* Give a reduction in school fees if possible.

* Develop specific steps to support female students.

Then when the school has opened again, UNICEF (2020) provides the following guidelines:

* Develop a model of decision making when schools can be closed and reopened.

* Improving the quality and quantity of school cleaning.

* Increase the use of hand sanitizers and cloth masks.

* Increase investment in distance learning to prepare yourself if later schools need to be closed again.

* Consider postponing the exam and if possible, all students may go up to class.

* Develop innovative learning methods for example online learning methods.

* Inform students about everything about the corona virus pandemic clearly, accurately, and easily understood. Avoid students from excessive fear.

* Prioritize support for children with special needs.

* Make sure learning material is accessible to students with limitations.

Based on the description above, it can be concluded that "New Normal" is the choice to recover from the COVID 19 pandemic, including in the field of education. Research on the planning, preparation, implementation, and evaluation of New Normal in the field of learning and teaching needs the attention of all parties, including academics. Academics can conduct the latest research and publications in this field. The results of research and publications on the impact of New Normal in the field of learning and teaching are believed to be beneficial in the field of education.

\section{REFERENCES}

Abidah, A., Hidaayatullaah, H. N., Simamora, R. M., Fehabutar, D., \& Mutakinati, L. (2020). The Impact of Covid-19 to Indonesian Education and Its Relation to the Philosophy of "Merdeka Belajar". Studies in Philosophy of Science and Education, 1(1), 38-49. https:// doi.org/10.46627/sipose.v1i1.9

UNICEF. (2020). Guidance for Covid-19 Prevention and Control in Schools. New York: UNICEF.

Worldometers. (2020). Reported Cases and Deaths by Country, Territory, or Conveyance. Retrived May 27, 2020, form https://www.worldometers.info/coronavirus/?utm_campaign=homeAdvegas1

Author (s):

*Binar Kurnia Prahani (Corresponding Author)

Department of Physics, Faculty of Mathematics and Natural Science,

Universitas Negeri Surabaya,

Jl. Ketintang, Surabaya 60231, Indonesia

Email: binarprahani@unesa.ac.id

Tsung-Hui Cheng

Graduate Institute of Science Education,

National Dong Hwa University,

No. 1 Sec. 2 Da Hsueh Rd., Shoufeng, Hualien, 97401, Taiwan

Email: editor.siletjournal@gmail.com 